ABAD, 2021; 4(7): 113-132

ISSN: 2618-6004

e-ISSN: 2636-8188 abad@nku.edu.tr

DOI: $10.32953 /$ abad.799418

\title{
ETHNIC CONFLICT MOVEMENTS: THE CASE STUDY OF BOSNIA AND HERZEGOVINA
}

\author{
Fetine YILDIRIMTÜRK BAYRAKTAR ${ }^{1}$
}

\begin{abstract}
If the conflict occurs due to political, social, economic, etc. reasons between two or more ethnic groups, it can be called 'ethnic conflict', which might or might not entail violence. The research on the meaning and quality of 'ethnic conflict' in the field of International Relations can be emphasized through the discussion of special cases selected via social sciences. This study aims to contribute to the studies of the ethnic conflict in international relations with the history and evaluation of dissolution of Yugoslavia, with the selected case of 'Bosnia and Herzegovina'. This article examines the issue of 'ethnic conflict' and the historical background in the scope of International Relations. It investigates the ethnic conflict movements of Bosnia and Herzegovina's chosen region, since the Cold War years with appropriate International Relations theories. In this context, the issue has been discussed within the framework of selected theories and historical background in order to evaluate the reasons for ethnic conflict in Bosnia and Herzegovina in the post Cold War era and the formation of an ethnic identity.
\end{abstract}

Key Words: Ethnic conflict, Ethnic Identity, Bosnia and Herzegovina, Theories of International Relations.

\section{ETNİK ÇATIŞMA HAREKETLERİ: BOSNA- HERSEK VAKA ÇALIŞMASI}

Öz: Şiddet içeren veya içermeyen, siyasi, sosyal, ekonomik ve benzeri herhangi bir nedenden dolayı, iki veya daha fazla etnik grup arasında eğer çatışma meydana gelirse 'Etnik çatı̧̧ma' olarak isimlendirilir. Uluslararası İlişkiler alanında 'etnik çatışma' konusunun anlam ve niteliğinin araştırılması, sosyal bilimler aracılığı ile seçilmiş özel vaka örnekleri ile tartışılarak vurgulanabilir.

$\mathrm{Bu}$ çalı̧̧mayla, Yugoslavya'nın tarihi ve dağılmasının genel bir değerlendirilmesiyle birlikte, seçilmiş vaka 'Bosna Hersek'i analiz

\footnotetext{
${ }^{1}$ Independent Researcher, Eastern Mediterranean University, fetine.bayraktar@emu.edu.tr. ORCID:0000-003-0614-9634.
} 
edilerek, Uluslararası İlişkiler'de etnik çatışma araştırmalarına katkıda bulunmak amaçlanmaktadır.

$\mathrm{Bu}$ makale, 'etnik çatışma' konusunu, Uluslararası İlişkiler kapsamında tarihsel arka planla birlikte incelemekte ve Soğuk Savaş yıllarından bu yana seçilmiş alan olan Bosna Hersek'te ki etnik çatışma hareketlerini uygun Uluslararası İlişkiler teorileri ile toplumun nasıl etkilendiğini araştırmaktadır. Bu kapsamda konu, Soğuk Savaş sonrası dönemde Bosna Hersek'teki etnik çatışmanın sebeplerinin irdelenmesi ve etnik kimliğin oluşumunun, değerlendirilmesi için seçilmiş teoriler ile birlikte tarihsel arka plan çerçevesinde tartışılmıştır.

Anahtar Kelimeler: Etnik Çatışma, Etnik Kimlik, Bosna-Hersek, Uluslararası İlişkiler Teorileri.

\section{Introduction}

According to the background of the conflict, the study introduces the reasons for ethnic conflict in Yugoslavia by presenting a historical part of the conflict. The paper will emphasize the policies and actions of different fighting groups of society regarding their separation ideologies under separate subtitles. In summary, the article will ask the questions (i) why the federal state of Yugoslavia separated, (ii) to what extent the parties decided to start rebellions to establish their independence or to construct a new nation-state.

The article starts to emphasize the meaning of conflict in international relations. According to the first part of the article, the basic information of conflict areas has introduced a general understanding of the formation era of conflict politics. In this context, the relative sources can find the definition of conflict and ethnic conflict and the backgrounds sources of ethnic groups and ethnic identity IR politics. The article continues with the brief historical background of Yugoslavia's dissolution to better understand the reasons for ethnic conflict in Balkan areas. The article then describes Bosnia and Herzegovina's demographic information for providing brief background about the causes of the ethnic movements in this area. The final part of the paper examines the meaning of the ethnic conflict and ethnic identity in the Balkans and the results of the ethnic conflict in society. The selected theories of International Relations examines how the individuals affected since the conflict years. In this context, several of the most appropriate theoretical perspectives choose to define the results of the ethnic conflict in Bosnia and Herzegovina. 


\section{The Meaning of Conflict in International Relations}

This part of the paper aims to explain the background of the ethnic conflict. Without understanding the sources of international conflict and ethnic conflict, it would not be easy to analyze the causes of ethnic conflict in Bosnia and Herzegovina. In this context, the paper will introduce the meaning of the ethnic conflict in the study's beginning parts.

According to the International Relations Theory, the natures of international conflict compose several types of violence governing state actors. In general, conflicts ruling by leaders who have power domination leads them to exercise their interests. Additionally, IR scholars define types of international conflicts as separating by tangible and less- tangible elements.The tangible substance interests are; (i) territorial border disputes, including secession attempts, (ii) conflicts over who controls national governments, and (iii) economic conflicts over trade, money, natural resources, drug trafficking, and other such economic transactions. The lesstangible class of conflict interests are; (i) ethnic conflicts, (ii) religious conflicts, and (iii) ideological conflicts. ${ }^{2}$

In brief, types of international conflicts open for discussion but, on the other side of view, all may define the types of conflict those either have observed or still observe at states in the world. "Ethnic conflict is quite possibly the most important source of conflict in the numerous wars now occurring throughout the world."

First and foremost, ethnic groups compose many people with the same family ground, language, culture, religion, and shared identity. Moreover, ethnic groups mainly based on nationalistic backgrounds and perspectives. From another perspective, ethnic conflict emerges when ethnic groups decide to rebel against redrawing the state's borders by using force and violence. For instance, if the state has ethnic minorities within the population of society, they become more unified and closer to each other than the majority group. Generally, they aim to govern the larger territory of the state to a continuation of its existence within the majority size of an ethnic group. For instance, this situation observed in Yugoslavia after the dissolution of

\footnotetext{
${ }^{2}$ Goldstein Joshua S., International Relations, Sixth Edition, Pearson Longman, United States, 2005, p. 175.

${ }^{3}$ Gurr Ted Robert, Peoples versus States: Minorities at Risk in the New Century, Washington DC: U.S.

Institute of Peace, United States 2000.
} 
the former republic, where ethnic Serbs decided to start ethnic cleansing policies towards Bosnians. ${ }^{4}$

Accordingly, the meaning of "ethnocentrism" explains the roots of the shared identity in ethnic groups defining in-group bias. That's the tendency to see one's group in favourable expressions, and an out-group in pessimistic terms, so in-group bias is understood as the social psychology that describes individuals who feel close to each other and protect other members group. For instance, it derived from an in-group bias can endorse intolerance and eventually dehumanization of out-groups, as in Bosnia and the Rwandan genocide, South African apartheid, the persecution of Jews and other minorities in Nazi Germany, and so forth. ${ }^{5}$

In short, it is challenging to argue a clear expression about; how individuals loyal to their own identity. For instance, consider the single ethnic identity states; their citizens are relatively willingly loyal to states' ethnic identity than multi-ethnic society-based states. For example, multi-ethnic states or societies use supervisions to achieve individuals' loyalty with materials such as flags, anthems, patriotic speeches, etc. ${ }^{6}$

In light of these arguments, now we can evaluate the case of Yugoslavia. During Tito Government's time, the authority has held to suppress the nation to establish their independent states. However, after his ruling period, all countries gradually demand to establish their independent nation-state. The reason is simple; if a state has a multi-ethnic society, it would be challenging to keep all groups together in a peaceful environment. Moreover, multi formation governments cannot effectively pursue equality principles, overall groups without considering their ethnic origins. That is so-called explain by the psychological assumptions of conflicts. In addition to these, other theoretical perspectives intended to describe the causes of ethnic conflicts.

\section{Background of Dissolution of Former Yugoslavian Republic}

The Area once known as Yugoslavia is a jumble of steep hills, dusty plateaus and impenetrable valleys- a terrible place to fight, but a wonderful place for guerrilla warfare ${ }^{7}$

First and foremost, the paper initiates to emphasize the historical background of the ethnic conflict in Yugoslavia. This part of the paper attempts to focus on the reasons for rebellions by different conflicting parties and analyze

\footnotetext{
${ }^{4}$ Gurr, ibid. pp. 187-189.

${ }^{5}$ Gurr, ibid. pp.189-90.

${ }^{6}$ Gurr, ibid. p. 192.

${ }^{7}$ Purvis Andrew, Anastasijevic Dejan, Graff James and Calabresi Massimo, "A Valley Full of Dangers", Time, March 2001, p. 28.
} 
those rebellions' results. 1980 considered the end of the era of Former Yugoslavia with Tito's death where its member states (Slovenia, Croatia, Macedonia, Bosnia, and Herzegovina, Serbia and Montenegro, and two autonomous states (Kosova and Methohia) could not have peaceful and tolerable relations anymore.

Following the years in Yugoslavia, an economic and social depression had started and the economy completely collapsed which caused tensions between old member states in 1989. No doubt, the new capitalist financial system has directly affected economic policies over the Republic of Yugoslavia. In addition to economic factors, there was political chaos where states sought to increase their political domination to establish a new independent state. For instance; the 14th Extraordinary Congress of the League of Communists of Yugoslavia in 1990, defines as the last Congress of Former Yugoslavia, was the end of the brotherhood among states because the single part system abolished (under the Serbian dominated authority), and multi-party elections took place after 1990.

Especially, since 1990 the newly elected Bosnian government's firmly decided to follow nationalistic ideologies, and they decisively protect only its nationalist interests. In short, an idea of a multi-party system could be a threat to provide a common single and unity of beliefs. It might be dangerous for elected nationalist governments on the way to establishing a new independent state.

Consequently, several rebellions and conflicts held between states in the way of independence, and by end of 1991, states had ambitions to establish their independent conditions. To sum up, the reasons for conflicts may summarize as; religion, language, culture, nationalism, and political domination. According to these, after Tito's death, the Republic of Yugoslavian's state could not tolerate their cleavages, and they started to follow policies against of principle of unity.

\section{The Case of Bosnia and Herzegovina}

The paper focuses on a selected case study in Bosnia and Herzegovina. This part of the paper composes a brief description based on the reasons and results of ethnic cleansing policies in the region better understanding.

The Republic of Bosnia and Herzegovina is not like the other republics of Yugoslavia, where most religious and national groups and communities had. According to the last census of population (1991), it had 4,364,574 by distribution: Muslim $43.7 \%$, Serbs $31.4 \%$, and Croats 17.3. Regard as the religious beliefs; the country had Orthodox Serbs, Catholic Croats, and Sunni Muslims; however, there was no religious association or practice used 
due to the socialist rule, Bosnians did not have strong intentions to practice religion regularly. ${ }^{8}$

Chart 1. Ethnic map of Yugoslavia based on 1991 census data.

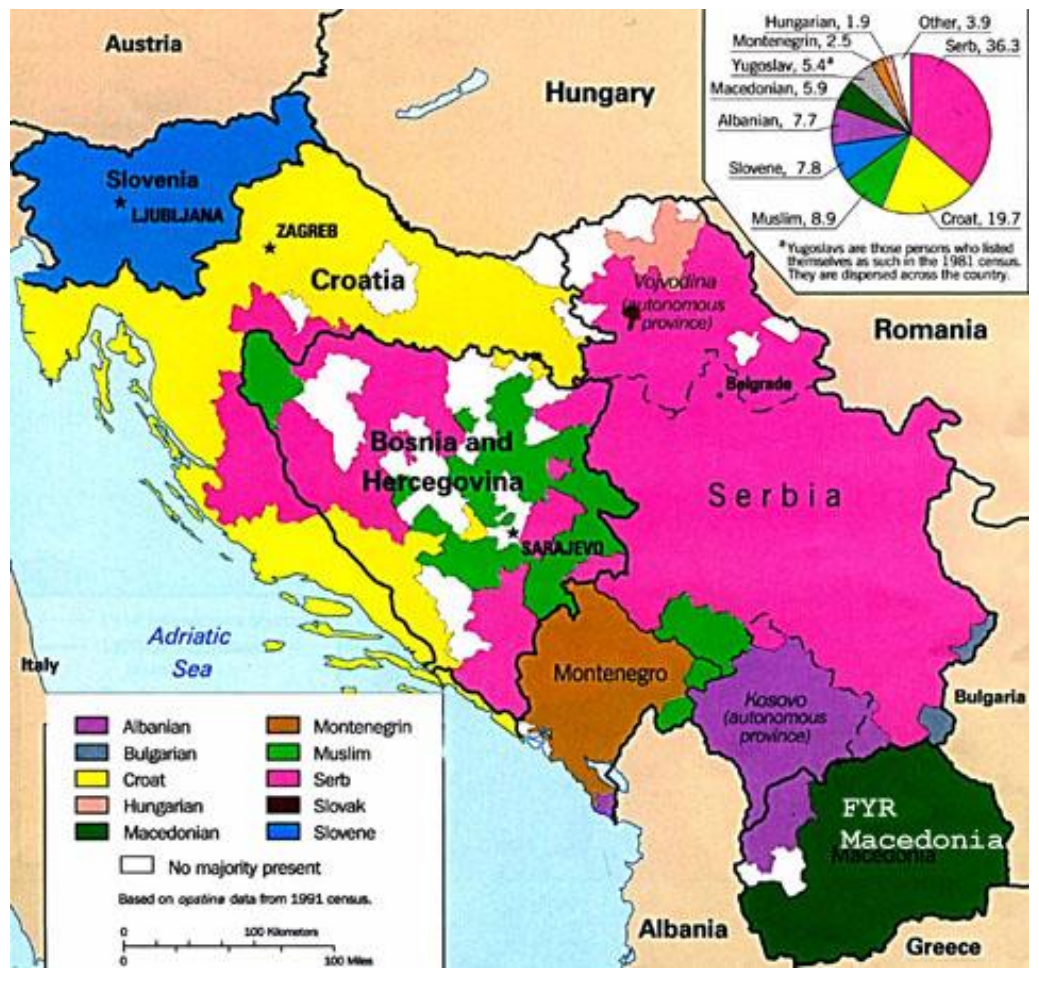

(Source: Ethnic map of Yugoslavia based on 1991 census data https://legacy.lib.utexas.edu/maps/europe/yugoslav.jpg)

Consider the political assumptions, the Bosnian government had accepted a multi-party election system in 1990, and all winning parties were on the nationalist side. The Bosnian government had two solutions in political issues and different political ways to follow; first, the political plan was "remains part of Yugoslavia". The second is "declare its independence". On behalf of these proposals, Bosnian Serbs supported the first plan in a referendum where Bosnian Croats and Muslims voted for the declaration of its independent state. During this period, a secret meeting organized between Serbs and Croatian" presidents (Milosevic and Tudjman) in 1991, which had

\footnotetext{
${ }^{8}$ Rogel, Carole, The Breakup of Yugoslavia and its Aftermath, Greenwood Press, Westport Conn. 2004, pp. 28-40.
} 
a new policy based on the division of their neighbouring republic, was included in supporting Serbia and Croats with chances for expansion. This policy may have explained the following political developments in Bosnia and Herzegovina. For instance, prior period of the Bosnian elections in 1992, the Serbian Democratic Party announced to its votes that;

"If Bosnia became independent they would once again be subjected to the laws of Muslim Landlords, agas, begs and pashas and that independence represented a rollback of everything Serbs has died for since 1804, if not 1389... [Serbs] were told that for hundreds of years they had been Bosnia's single largest party community and that in the last twenty-five years the Muslims had suddenly "outbred them"."

After the Bosnian and Herzegovina's independence, the Serbs establish another independent state inside Bosnia, Serbian Bosnia and the Herzegovina Republic and Croatians. They live in Bosnia establish their independent state too. These situations were the core point of the war. Milosevic's speech about his dreams of war;

"I am motivated by the pain that I see here but also inspired with hope he is presenting himself as a speaker of goodwill, willing to help his people. Further on he states we are facing disunion because leading Serbian politicians are favouring compromises which damage their own people... We need tolerance, cooperation and even equality (...) but Serbs have to be leaders because if they cannot be at the head, we will forever be in the back." 10

The war has continued in Bosnia Herzegovina from April 1992 until October 1995. Firstly, the Bosnian Serb army targeted to attack eastern and northern parts of Bosnia to create and continue creating Serb-held territory because Serbs mainly lived in the western region of Bosnia. Moreover, they attacked the capital city Sarajevo were all crucial headquarters located. Regarding all those strong war policies, the government of Bosnian asked for help from the United Nations. However, despite the UN peace forces and their help, the war was continuing and concentration camps constructed and crimes against civilians started by late $1992 .^{11}$

For instance, Radovan Karadžić (Bosnian Serb Leader) stated as:

${ }^{9}$ Carmichael Cathie, Ethnic Cleansing in the Balkans, Nationalism and the Destruction of Tradition, Routledge, London 2002, p.33.

${ }^{10}$ Kisicek Gabrijela, The Rhetoric of War- Former Yugoslavia, Journal of Art \& Humanities, Vol 2, No 8., 2013, pp. 78-79.

${ }^{11}$ Vulliamy, op. cit., p. 49. 
"This is the path that you want to take Bosnia and Herzegovina on, the same highway of hell and death that Slovenia and Croatia went on. Don't think that you won't take Bosnia and Herzegovina into hell, and the Muslim people maybe into extinction. Because the Muslim people cannot defend themselves if there is war here." 12

Radovan:

"He presents his virtue by identifying himself with the Serbian ... God is our witness we have suffered enough, we are forced to fight; we have to save our houses. Like Milošević he presents himself as a peaceful person who opposes conflict but is now forced into it. He advocates war but only because it is the sole remaining solution."

The Serbian policy of 'ethnic cleansing' officially started towards Bosnians, especially to the Muslims, and the size of national groups became 1.5 million (a third of the Bosnian population). Since these dramatic war times, it takes the attention of the international community. For instance, International Red Cross gained a right to join the concentration camps. They reported Serbs as the guiltiest side based on violation against humanity, which includes 20.000 rapes against women. In this context, the European Union and United Nations decided to establish a permanent Geneva Conference to find a comprehensive solution for the Bosnian problem. Then, Humanitarian aid started to go to Bosnian civilians, and United Nations established the International Court to prevent war criminals. Additionally, NATO figured out its forces for the protection of civilians. ${ }^{13}$

In 1993, the peace proposal (Vance-Owen plan) prepared with the international community's support, but it did not accept, and the war was continuing. With regard as international reports, the days of war recorded 1000, it had dead civilians around 200.000, and a million refugees and 1.1 million of whom now live in out of the state. (30 December 1994).

The new policies started to implement by the diplomacy of United States of America, and Contacting Groups created composed of France, Germany, Great Britain, Russia and the United States (US). The group started to use tactics of "carrot and stick policy" against conflicting Serbian forces. Consequently, after US diplomacy's peacebuilding efforts, The Dayton Agreement (14TH December 1995) signed. It means the conclusion of the war in Bosnia and Herzegovina, its document authorized by Implementation

\footnotetext{
${ }^{12}$ Radovan Karadžić, 14 October 1991.

https://en.wikiquote.org/wiki/Radovan_Karad\%C5\%BEi\%C4\%87\#Quotes, http://www.focus-news.net/404/.

${ }^{13}$ Kisicek, ibid.p. 80.
} 
Force (IFOR) headed by the US. The agreement approved its sovereignty, and independence, and the state now have two parts which are first: the Muslim-Croats federation that controls $51 \%$, second: the Serbian Republic controls $49 \%$ of Bosnian territory. ${ }^{14}$

The next part of the paper will expound on the theoretical background of the ethnic conflict. In the next part of the paper, the types of ethnic conflict will be explained by the ethnic conflict policies in Bosnia and Herzegovina.

\section{Theories of Ethnic Conflict: Case of Bosnia and Herzegovina}

An example of the ethnic war in Bosnia and Herzegovina is the most dramatic conflict in recent years in Europe. It has the most extensive documentation of conflict with the rape victims.

First of all, Kaufman focused on ancient hatreds which are the factor of causes of ethnic conflict and it is a necessary part of understanding ethnic cleansing and mass murders during ethnic violence. ${ }^{15}$ For instance, he stated that ethnic war in the region of Bosnia and Herzegovina during the 1990s was neither surprised nor suddenly began because ancient and savage hatreds had affected society. He argued that ancient hatred has deep historical roots in this context, but it still has importance and constant influential factor of ethnic wars.

Following the reasons for ethnic conflict in Bosnia and Herzegovina, Kaufman's argument either relevant or not relevant. One of the reasons is the influence of historical background, and ancient hatred cannot easily remove. Indeed it has continued to affect the next generations of society. His study is relevant to the Bosnia War because of solid historical background influences of Bosnian cultures, such as fears and tensions. Moreover, as Kaufman argued, the ethic war was not suddenly occurred in 1990. Since the death of Tito (1980), the relationship between ethnic groups in society gradually became worse where tensions were correspondingly increased. It means that, if the tensions are progressively growing, it will parallel the effect arising from fear and trust, which leads to having security problems between ethnic groups. ${ }^{16}$

\footnotetext{
${ }^{14}$ Caplan Richard, Assessing the Dayton Accord: The Structural Weaknesses of the General Framework Agreement for Peace in Bosnia and Herzegovina, Diplomacy and Statecraft, 11:2, 2000, pp.213-232.

15 Kaufman Stuart J., 'Modern Hatreds The Symbolic Politics of Ethnic War, Cornell University Press, the United States of America, 2001.

${ }^{16}$ Kaufman Stuart J., 'Modern Hatreds The Symbolic Politics of Ethnic War, Cornell University Press, the United States of America, 2001.
} 
However, Kaufman's theory of ancient hatred cant enough to explain the reasons for ethnic conflict. Because it is not the only factor that affects the emergence of ethnic violence, for instance, modern and current factors can be considered a good reason for ethnic violence and ancient hatreds. Accordingly, there is the decisive influence of historical background on ethnic conflicts. Still, without regarding current factors and their effects on conflict, the theory would not apply to the Bosnia Case. In short, his theory is not enough to explain ethnic violence in Bosnia and Herzegovina.

In the case of Bosnia and Herzegovina, spreading the idea of capitalism was the main current issue that considered a factor for the conflict. For instance, capitalism's influence did not have a historical perspective, or it does not explain the meaning of ancient hatred in Bosnia. However, due to the expansion of capitalism worldwide, it was directly or indirectly affected the situation in Bosnia. Simultaneously, we may argue that capitalism might affect the Serbian policies whose economic dominance compared to Bosnians and capitalist thoughts lead them to use their economic powers against Bosnians. Consider this way of view; we can say that as a capitalist new and changing world policy affected Serbians aims in the form of establishing their independent state.

From another theoretical perspective, Horowitz used the theory of "tradition and modernization" to analyse the motives of ethnic groups towards ethnic conflict. He argued that tradition would not be a relevant element for evaluating ethnic groups in an ethnic conflict. The reason he addressed that ethnic groups relationship usually affects by current movements rather than earlier policies. In this context, he summarize as;

"History can be a weapon, and tradition can fuel ethnic conflict, but a current conflict cannot generally be explained by simply calling it a revived form if an earlier conflict., 17

On the other hand, the modernization theory of Horowitz argued that modernization creates an unequal distribution of social and economic opportunities, and this leads to increase group tensions. ${ }^{18}$

For instance, objectives of modernization theory quoted as follow;

"People's aspirations and expectations change as they are mobilized into the modernizing economy and polity. They come to want, and to demand, more-more goods, more recognition, more power." 19

\footnotetext{
${ }^{17}$ Horowitz Donald L, Ethnic Groups in Conflict, United States: University of California Press, 2000. p. 99.

${ }^{18}$ Horowitz, ibid., p. 100.
} 
According to Horowitz's modernization theory, its objectives are appropriate in the case of Bosnia and Herzegovina. The reason is that the modern economy and the new political basis were affected by Bosnia's socioeconomic conditions. For instance, from 1989-1990, they had ambitions to change the state's political order, called political reconstruction (single-party government to multi-party government). In addition to the theory of Horowitz, he emphasized that the group of elite individuals who has vital interests based on the benefits of modernity such as better jobs, schools, prestige, and power. ${ }^{20}$ From this point of his theory, it can be relevant to understand and explain the source of ethnic violence in Bosnia and Herzegovina.

This idea can be an example of the influences of modernization. Regarding Bosnia's case, the new political reconstruction policy caused the ethnic separation of state, and dramatic ethnic conflict has emerged after this development.

The paper emphasises the roles of elites and leaders of society under the scope of the selected case. First of all, Kaufman underlined the meaning of manipulative leaders to possess causes of ethnic war and its dramatic implementation processes such as mass murdering, sexual violence, rapes, etc. In addition to this, he argued that the elite of society and political leaders drive the leading role to provoke or instigate ethnic groups against each other to save and increase their powers the same as domination over its followers. ${ }^{21}$

According to these, elite individuals and leaders of society have a governing role for figure out the circumstances of ethnic tensions and conflict. The reason is that there are other groups of individuals in the society who are neither elite nor leaders; they are always tending to follow the directives of elites and leaders of society. Therefore, the capabilities of elites or leaders are essential factors to affect society towards ethnic violence.

In Bosnia and Herzegovina's case, both Horowitz's and Kaufman's theoretical perspectives are relevant and provide sources to understand; how elites and leaders oriented societies within the ethnic wars? In this respect, Kaufman mentioned Milosevic (Serbian Leader in Yugoslavia), who provoked people to overthrow regional leaders (under the Republic of Yugoslavia). He urged people to start an internal war to declare a new

\footnotetext{
${ }^{19}$ Horowitz, ibid., p. 100.

${ }^{20}$ Horowitz, op. cit., p. 100.

${ }^{21}$ Kaufman Stuart J., 'Modern Hatreds The Symbolic Politics of Ethnic War, Cornell University Press, the United States of America, 2001.
} 
independent state. In this manner, he increases its leadership status by governing a new nation-state. Therefore, he had strong leadership capability to utilize all tactics of war to become his dreams true.

Considering the economic interest and competition, Kaufman's two assumptions (ancient hatreds and manipulative leaders) of ethnic war, he also added that an economic rivalry influences the causes of ethnic wars. ${ }^{22}$ $\mathrm{He}$ argued that individuals come together and create a group for improving their economic gains refer to; how much they can get more. For instance, one of the conflict scholars, Susan Woodward (Brooking Institution Scholar) evaluated relations between importance of economic rivalry and fall of Yugoslavia. She introduced that;

"... the decade-long economic stagnation which, as is typical in such cases, made all other conflicts including ethno-nationalist ones more tense. Although, Yugoslavs increasingly agreed that economic reform was necessary, they disagreed over the sort of reform they should adopt because of regional differences across the Yugoslav economy." 23

According to Kaufman, he refused the perspective that ethnic groups in Yugoslavia did no rebel because of the economic stagnation problem. $\mathrm{He}$ argued that if ethnic groups started to war due to economic difficulties, they would not opt to destroy principles of the rule of law which is the main rule to achieve standard economic policies. As briefly, Woodward's' study does not correctly answer the causes of the ethnic war in Bosnia and the reasons for Serbian government's war policies towards Bosnian citizens. Although, there is an acceptance that it faced an economic stagnation problem in Bosnia (during 1989-1990, prior period of war) and it influenced the policies of Serbian government, it can't be considered as the leading cause of ethnic conflict towards Bosnian civilians.

Consider the case of Bosnia and Herzegovina, it had economic problems and those either directly or indirectly affect individuals' living conditions. Still, it did not have an enormous effect on to shoot of the ethnic war. Bosnia war can be one of the best examples of ethnic war cases that faced pure ethnic cleansing policies such as mass murders; concentration camps, etc.

By the assumption of economic rivalry and evaluating its relevancy based on the case of Bosnia and Herzegovina, Kaufman's theoretical perspective is

\footnotetext{
${ }^{22}$ Kaufman J. Stuart, 'Modern Hatreds The Symbolic Politics of Ethnic War, Cornell University Press, the United States of America, 2001, p. 9.

${ }^{23}$ Kaufman, Ibid, p. 9.
} 
relevant to explain the influence of economic rivalry in Bosnia. Kaufman summarized that;

"Ultimately, behaviours of this kind must explained by reference to the factors mentioned in the "ancient hatreds" stories- economic or instrumental rivalry is not enough., 24

Kaufmann deals with the Bosnian case, Serbian military groups composed of volunteers for solving their problems, surely they may have self-interest as like all human beings but this does not enough to explain ethnic movements in Bosnia. The reason summarizes as Bosnian civilians had across one of the bloodiest conflict movements such as acts of torture and murder. If an economic rivalry has one of the ground element of the Bosnian war, its policies would assume as a different way of attack and it would not base on ethnic war policies such as mass murder, concentration camps. ${ }^{25}$

From another perspective of view, Horowitz pursued to analyse the sources of conflict based on the meaning of economic interest. In this perspective of view, he stated that;

"The fundamental deficiency of the class theory of ethnic conflict is that it credits with conflict-producing power every rationally competitive interest that can conceivably be identified, while ignoring all of the forces that work against the emergence of such competitive interests. In fact, there are many forces that operate to inhibit competitive relationships and therefore blunt the impact of economically based conflict. ${ }^{, 26}$

In short, he explained the influence of economic rivalry in ethnic conflicts by underlining the significant factor of unequal conditions and opportunities in a society that creates class conflict problems in general. It means that competition emerged between the different classes of society, leading to face tensions among groups.

However, according to Horowitz, his perspective on economic interest may appropriate for other related conflicts studies. It can take into account as one of the critical factors leading to causes of war. However, this perspective does not seem enough to explain Bosnia's case because a cause of ethnic conflict in Bosnia does not make it possible to explain economic interest and competitive approach of ethnic war. The reason is that war's progression and

\footnotetext{
${ }^{24}$ Kaufman, op. cit., p. 9 .

${ }^{25}$ Kaufman, op. cit., p. 9.

${ }^{26}$ Horowitz, op. cit., p. 108.
} 
policies make it impossible to demonstrate that war based on leaders or ethnic groups' economic interests.

On the other hand, dealing with the causes of ethnic conflict, psychological sources are essential to analyse the cause of ethnic wars. Kaufman argued that the case of ethnic conflict starts with emotional approaches rather than economic and linguistic assumptions.

For instance, he highlights the meaning of prejudice which plays a vital role in ethnic conflicts in terms of negative or hostile feelings against other group members. According to Kaufman's Symbolic politics theory, that argues the myths of groups which are fears, violence and chauvinist feelings and beliefs, are the key factors in creating emotion-laden symbols that make mass hatred for chauvinist elites to provoke and make extremist policies popular. ${ }^{27}$ In short, Kaufman stressed that emotional tools (hostility, prejudice) of ethnic groups appear due to the fear of destruction and loss of ethnic identity.

On the other hand, consider as Kaufmann's, he defines the three factors of creating ethnic war: hostile masses, belligerent leaders, and inter-ethnic security dilemmas. Therefore, his theories are one of the most important ones when the case is understanding ethnic wars. ${ }^{28}$

According to the ethnic group identity, the paper aims to touch on aspects of large-group identities regarding the causes of ethnic war. This part mainly introduced with the theoretical study of Vamik Volkan to define significant ethnic group identities and their influence in case of emergence of ethnic conflicts. According to Vamik Volkan, he describes how individuals come together and create large ethnic groups and affect this process. Volkan explains the origin of significant group identities follow as:

"As humankind evolved, in addition to the necessities of nutrition, warmth, and weapons, other meanings were attached to the physical items for which neighbouring tribes competed. Some of these items, such as feathers and claws, became symbolic, valued not only for their physical benefits, but also for the psychological benefits they provided, such as enhancing self-esteem. These symbols reflected the group's conscious and unconscious needs and wishes and slowly evolved into the colours, flags, songs, dress modes, and other cultural indicators that keep shared identities alive and reflect the group's

\footnotetext{
${ }^{27}$ Kaufman Stuart J., 'Symbolic Politics or Rational Choice? Testing Theories of Extreme Etnic Violence', International Security, Vol. 30, No.4, spring 2006, p. 47.

${ }^{28}$ Kaufman Stuart J., 'Spiralling to ethnic war: elites, masses, and Moscow in Moldova's Civil War, International Security, Vol. 21, No.2, Fall 1996, p. 109.
} 
realistic and mythical history. Shared language, a sense of attachment to the land where ancestors were buried, and shared religion further shaped the identity of the group and differentiated it from the other, potential enemy." 29

To sum, he argued that individuals always request to live where there is a standard value, culture, and religion sharing group; otherwise, they do not feel safe and relax.

Furthermore, Volkan added that significant group identities would work as invisibly power in ethnic conflict. He argued that if individuals are under specific threats, awareness of group identity will automatically increase (where they all share the same religious, ethnic, national, and racial characteristics) to fight with the actual threat.

Additionally, Volkan also underlined the analogy of a large canvas tent for more profound investigation of the large groups' psychology. His perspectives regarding as the canvas tent:

"... in terms of leaning to wear, from childhood on, two layers of clothing. The first layer fits snugly. This is one's personal identity. The second layer, the ethnic (emotionally bonded large group) layer, is a loose covering that protects the individual in the way that a parent, close family member, or other caregiver protects one. Because this garment is not formfitting, it also shelters other members of the group and resembles, in a sense, a large canvas tent. ${ }^{, 30}$

Moreover, Volkan stated that there is a vital role for society's leaders to protect tents over the community. He said that leadership is the most potent leverage power for protecting the collapse of the tent. For instance, there is an influence on a tent's collapsing if the leader has psychological uncertainties. In short, if the leader does not explore expecting or unexpecting threats for society, and do not clearly express his policies, it would cause partition in a large group.

Regarding the case of Bosnia and Herzegovina, Volkan's arguments about the origin of large-group identity and large canvas tent theory are relevant to analyse sources of Bosnian ethnic conflict. As I mentioned in the previous parts of the paper, we can divide ethnic war in Yugoslavia into two parts before and after Tito's governance. Let's look at leadership roles as introduced by Volkan. It gives the theoretical background that helps for

29 Volkan Vamik, Blood Lines: From Ethnic Pride to Ethnic Terrorism, Basic Books Publisher, the United States, 1997, p.25.

${ }^{30}$ Volkan, ibid. pp. 27-28. 
more profound understanding based on how leaders' authority or governance would cause to start an ethnic conflict, how leaders can prevent ethnic tensions in large ethnic groups. For instance, after Tito's death, ethnic groups have started partition in their sizeable Yugoslav tent, and they continued to dissolve the Republic of Yugoslavia, to establish their own separate nation's states.

"As the former Yugoslavian example illustrates, when a large group is regressed and people wonder, "who are we now?" the personality of the political leader becomes an important factor in the scenario, one that has considerable influence on societal and political processes. "31

When Tito's authority ended in Yugoslavia, the large Yugoslavian tent could not survive for a long time. For instance, as Volkan mentioned, the large group, which comprises ethnic, national, religious aspects, defines the same subjective routines and practices of thousands or millions of peoples. The main goal of the members of large groups is to stabilize, protect, and repair their group identity, and the feeling of 'chosen trauma' is one of the most essential supplement of this identity. ${ }^{32}$ Because it calls the mental representation and perspective of the group identity.

In conclusion, as Volkan mentioned, there is one personal identity based on an individual's interests, and the other one is a significant group identity based on the state's ethnic identity. Considering the theory of ethnic tents, it comprises personal and large group identities because individuals also act under large-group identity influences (it composes individuals). Instead of individuals having their own identity, they act under the authority of largegroup identity as well. This may be considering why a person can eat a meal and drink coffee together with other ethnic groups' people. Another day, they can threaten, survive, and kill each other, such as Bosnian and Herzegovina (between Serbs and Bosnians) during the ethnic war.

On the other hand, the theory of Volkan's 'chosen trauma' helps for better understanding of how individuals willing to stay under the authorities of large ethnic groups and obey their rules. Volkan introduced as;

"The chosen trauma becomes a significant marker for the large group identity. Furthermore, it may create a foundation for the society's development of an exaggerated entitlement ideology that, under new historical situations such as a threat to group's identity, can be

\footnotetext{
${ }^{31}$ Volkan Vamik, 'Chosen Trauma: The Political Ideology of Entitlement and Violence', Paper Presented in Berlin, 2004, p.12.

32 Volkan Vamik, 'Transgenerational Transmission and Chosen Traumas: An Aspect of Large- Group Identity’, Group Analysis, Vol 34, No.1, 2001, p.79.
} 
manipulated by political leaders to develop new political programs and / or take new actions supported by this ideology.",33

According to the theory of 'chosen trauma', it fits well into the analysis on causes of ethnic war in Bosnia. The reason is that, during the prior period of ethnic war, leaders of conflicting sides (especially Serbs) utilized the methods of chosen trauma to create large ethnic groups against others. For instance, they used the theory to achieve a larger ethnic group's most vital identity, which helps them keep group members closest. Consider the Serbian policies during 1989-1990; we can observe that their policies shift to the execution of solid nationalistic policies for reaching political dominance over other nations. As briefly, they used to pursue nationalist propaganda against Bosnians which fire to ethnic war among them.

The past practices, especially tragic experiences, are not easily forgotten and transfer quickly from one generation to another. The past experiences have a strong influence that shapes the personal identity. ${ }^{34}$ For instance, people who are part of the community, even though they will learn the truth in the future, maintain and continue to remember the untruth beliefs. Additionally, an influence of shared mental symbol of chosen trauma on a group's identity is also more effective than historical reality. ${ }^{35}$ Simultaneously, psychological truth is more significant than biological truth in terms of inflamed ethnic hatred. For that reason, psychological processes, even the unconscious practices, can help to understand actions of horrible human traumas and the background of the fire point of conflict. ${ }^{36}$ This study argues that the theory of chosen trauma is the most relevant to analyse Serbian leaders' policies' deals with how they exercise it into their large ethnic groups and how they can keep its members together and possess their loyalties.

\section{Conclusion}

It seems that Serbians had an influential leader, unlike Bosnians in their history. For instance, consider as Bosnian leader's speech, he appeared that he lost the war before it started. If we compare Serbs and Bosnian's economic conditions, of course, Serbs have domination power, which means

${ }^{33}$ Volkan Vamik, Large-group psychodynamics and massive violence, Ciênc \& Saúde Coletiva, Vol.11, No.2, 2006, p.1.

${ }^{34}$ Music Lejla, Jeftic Alma, Draganavic Selvira, Psycho-social Aspects of Trauma and its transmission in Postwar Bosnia-Herzegovina, Electronic Journal of Political Science Studies, Vol:5 No:1, 2014, p.42.

35 Shatzmiller Maya, Islam and Bosnia: Conflict Resolution and Foreign Policy in Multiethnic States, McGill-Queen's Press (MQUP), United States, 2002, p.87.

${ }^{36}$ Shatzmiller, ibid. p. 97. 
that they have more substantial and well prepared military forces than Bosnians. However, it may introduce the worst leadership capability to declare or accept the lost position at the first stage of the war. In brief, a leader's abilities are not considered the only factor for causes of war, but their motivations always have leverage over society to provoke war.

Consider the economic aspects of the ethnic conflict, it is not entirely appropriate to explain and evaluate and describe the reasons for the war in Bosnia. For instance, Serbian ethnic groups risked their own life for cleaning their ethnic origins of the Bosnian population. Assuming that the influence of economic interest is one of the important assumptions of conflict reasons, it is not meant to analyse the Bosnian case under this approach. Considering this perspective, while studying the Bosnian subject, economic interest is inconsistent with explaining the ground and progression of ethnic war policies in Bosnia. To sum up, ethnic conflict policies in Bosnia based on less-tangible approach rather than tangible and materialistic approaches.

Regarding Bosnia's case, both Kaufman's and Horowitz's arguments deal with the psychological aspects of ethnic conflict that are relevant to explain the ethnic conflict in Bosnia and Herzegovina. For instance, Kaufman argued that prejudice also played a vital role during the ethnic war. The Serbian government's war policies, such as; mass murders, women rape, and concentration camps, show that they did not tolerate Bosnian Muslims; Serbian wants to exist solely within the territory and tried to destroy other ethnic groups in Bosnia.

On the other hand, Kaufman provides an idea that we can understand why nations continue to destroy other ethnic groups instead of facing the exact cost. Because based on the psychological perspective of ethnic groups have mutual fears; supposing that they will lose their ethnic identity by other groups' by ethnic cleansing policies.

According to Horowitz, he continued to analyse the sources of ethnic conflict with the psychological roots of ethnic groups. Previously, he introduced as; without consideration on psychological effects (emotional basis), it is impossible to understand sources of ethnic conflict. He stated that intergroup psychology is essential to understand the collective policies of ethnic conflict. Moreover, he mentioned that the fear of extinction caused an ethnic war between different groups and feelings of hostility to motivate groups to use violence.

Additionally, as Horowitz underlined, prejudice is a psychological aspect that can be considered the starting point of ethnic conflict in Bosnia Herzegovina. If we focus on the Serbian policies of ethnic conflict against 
Bosnian Muslims, we do not avoid considering the conflict's psychological aspects. The reason is that Bosnia had a multi-ethnic society, and they were living together under the rules of respect and tolerance (sure, they may have some tensions between nations but not that much). When the prejudice and hostility idea start to use by Serbian leaders, it began to affect its followers.

In short, emotions have a core element, and leaders always prefer psychology to increase the feeling of hostility and spread prejudice within society against other ethnic groups. For instance, Serbian leaders utilized and pushed this tactic of ethnic conflict over their followers, and it helps them grow tensions between the two ethnic groups of the region.

In conclusion, after Yugoslavia's dissolution, the lack of political management creates very bloody ethnic wars in the region. People suffered a lot and had to leave their homes and lands, and most of them became a refuge in other neighbouring countries. Even today, the war's psychological and social consequences and its social effects are apparent. The 90s is not a distant history for us; this is the main reason for the selected Bosnia and Herzegovina to define the ethnic conflict. Finally, this study's sources and discussions tried to underline the importance of the expression of ethnic identity without any threat and pressure from any individual or group.

Bibliography

CAPLAN, Richard, 'Assessing the Dayton Accord: The Structural Weaknesses of the General Framework Agreement for Peace in Bosnia and Herzegovina', Diplomacy and Statecraft, 11:2, 2000.

CARMICHAEL, Cathie, Ethnic Cleansing in the Balkans, Nationalism and the Destruction of Tradition, Routledge, London 2002.

GOLDSTEIN, Joshua S., International Relations, Sixth Edition, Pearson Longman, United States, 2005.

GURR, Ted Robert, 'Peoples versus States: Minorities at Risk in the New Century', Washington DC: U.S. Institute of Peace, United States 2000.

HOROWITZ, Donald L, 'Ethnic Groups in Conflict, United States,' University of California Press, The United States of America, 2000.

KAUFMAN, Stuart J., 'Spiralling to ethnic war: elites, masses, and Moscow in Moldova's Civil War', International Security, Vol. 21, No.2, Fall 1996.

KAUFMAN Stuart J., 'Modern Hatreds The Symbolic Politics of Ethnic War', Cornell University Press, The United States of America, 2001.

KAUFMAN Stuart J., 'Symbolic Politics or Rational Choice? Testing Theories of Extreme Etnic Violence', International Security, Vol. 30, No.4, Spring 2006.

KISICEK, Gabrijela, 'The Rhetoric of War- Former Yugoslavia', Journal of Art \& Humanities, Vol 2, No 8. 2013.

MUSIC Lejla, Jeftic Alma, Draganavic Selvira, 'Psycho-social Aspects of Trauma and its transmission in Postwar Bosnia-Herzegovina', Electronic Journal of Political Science Studies, Vol:5 No:1, 2014. 


\section{Bayraktar, F. (2021). Ethnic Conflict Movements: The Case Study of Bonia}

and Herzegovina. ABAD, 4(7), 113-132.

PURVIS, Andrew, Anastasijevic Dejan, Graff James and Calabresi Massimo, “A Valley Full of Dangers", Time, March 2001.

ROGEL, Carole, 'The Breakup of Yugoslavia and its Aftermath, Greenwood Press', Westport Conn. 2004.

SHATZMILLER, Maya, "Islam and Bosnia: Conflict Resolution and Foreign Policy in Multi-ethnic Sates”, McGill-Queen's Press (MQUP), United States, 2002.

VOLKAN, Vamik, “Blood Lines: From Ethnic Pride to Ethnic Terrorism', Basic Books Publisher, the United States, 1997.

VOLKAN, Vamik, "Transgenerational Transmission and Chosen Traumas: An Aspect of Large- Group Identity”, Group Analysis, Vol 34, No.1, 2001.

VOLKAN, Vamik, “Chosen Trauma: The Political Ideology of Entitlement and Violence', Paper Presented in Berlin, 2004.

VOLKAN, Vamik, "Large-group Psychodynamics and Massive Violence”, Ciênc \& Saúde Coletiva, Vol.11, No.2, 2006.

Online sources:

Radovan Karadžić, 14 October 1991.

https://en.wikiquote.org/wiki/Radovan_Karad\%C5\%BEi\%C4\%87\#Quotes, http://www.focus-news.net/404/ (15.07.2020). 